\title{
Kajian Kitosan Sebagai Agens Pengendali Penyakit Busuk Buah Kakao (Phytophthora megakarya L.)
}

\section{(Study of Chitosan as a Control Agent of Fruit Rot Disease of Cocoa [Phytophthora megakarya L.])}

\author{
Septiana $^{1 *}$, Suskandini Ratih Dirmawati'), Rusdi Evizal ${ }^{1)}$ \\ 1) Jurusan Agroteknologi Fakultas Pertanian Universitas Lampung, Jl. Prof. Soemantri \\ Brodjonegoro, Telp./Fax.: (0721)704946/(0721)770347, Kode Pos: 35145 \\ E-mail: septiana_twin@yahoo.com
}

\begin{abstract}
Indonesia is a cocoa producing country with production of 425 thousand tons per year. However, production continues to decline, among others, caused by Phytopthora megakarya cause of fruit rot disease of cocoa, therefore it is necessary effective control of cacao fruit rot disease. This study aims to determine the effect of chitosan concentration on the growth of $P$. megakarya cause of fruit rot disease in vitro. The research was conducted at Plant Disease Laboratory, Department of Agrotechnology, Faculty of Agriculture, University of Lampung, from November 2012 to January 2013. V8 media research as a medium of growing $P$. megakarya. The workshops are arranged in a complete randomized design (CRD) consisting of (1) V8 media without chitosan (2) V8 media 0,2\%, (3) V8 media 0,4\%, (4) V8 media 0,6\%, (5) ) V8 media 0,8\% (6) medium V8 fungicided copper oxide $56 \%$, and replicated six times. The results showed that the colonies growth of $P$. megakarya 6 days after incubation in V8 media 0,4\%,0,6\%,0,8\% more depressed than growth on the V8 without chitosan media.
\end{abstract}

Keywords: concentration, disease control, in vitro, V8 media

DOI: http://dx.doi.org/10.25181/jaip.v6i2.977

Diterima: 10 Juli 2018 / Disetujui: 27 September 2018 / Diterbitkan: 12 Oktober 2018

\section{PENDAHULUAN}

Indonesia merupakan salah negara penting penghasil kakao. Produksi kakao di Indonesia mencapai 425 ribu ton per tahun. Di Indonesia, sentra penghasil kakao salah satunya adalah Provinsi Lampung (Prameswita et al., 2014; Lestari \& Purnomo, 2018). Menurut Adedeji et al. (2008) penyakit busuk buah kakao disebabkan oleh spesies Phytopthora megakarya. Intensitas serangan patogen akan semakin tinggi apabila didukung dengan iklim mikro yaitu kelembaban lingkungan yang tinggi (Duniway, 1983). Pengendalian penyakit busuk buah kakao yang saat ini dilakukan pada umumnya dengan cara mekanik, yaitu memetik dan membuang buah kakao yang memiliki gejala busuk buah, pemangkasan batang tanaman kakao, dan batang pohon pelindung, dan sanitasi terhadap gulma di sekitar tanaman kakao juga dapat mengurangi busuk buah kakao (Semangun, 1996). Pengendalian lain yang umum dilakukan yaitu penggunaan fungisida sintetik (Ramlan, 2010). Pengendalian penyakit busuk buah kakao yang diperlukan adalah pengendalian 
yang tidak membutuhkan biaya yang besar, ramah lingkungan, serta tidak meninggalkan residu racun yang berbahaya (Prasetyaningrum et al., 2007).

Kitosan merupakan senyawa kimia yang berasal dari bahan hayati kitin. Menurut Manurung (2005), bahwa kitosan terkandung pada udang 70\%, kepiting 69\%, ulat sutra 44\%, labalaba 38\%, kumbang 35\%, kalajengking 30\%, jamur 5-20\%, dan cumi-cumi 3-20\%. Pemanfaatan kitosan sebagai pengendali patogen telah banyak diteliti. Menurut Gotama (2011), bahwa media V8 berkitosan dengan konsentrasi 1\%-6\% mampu menghambat pertumbuhan Phytophthora sp. Secara in vitro. Kemampuan kitosan dalam mengendalikan jamur adalah dengan mengikat nitrogen yang berada di dalam DNA jamur serta merusak membran biologis jamur, sehingga menyebabkan protein jamur menjadi rusak (Simpson et al., 1997). Penelitian ini bertujuan untuk mengetahui pengaruh konsentrasi kitosan pada pertumbuhan $P$. megakarya penyebab penyakit busuk buah kakao secara in vitro.

\section{METODE PENELITIAN}

Penelitian dilaksanakan di Laboratorium Penyakit Tumbuhan Jurusan Agroteknologi Fakultas Pertanian Universitas Lampung dari bulan November 2012 sampai dengan Januari 2013. Alat-alat yang digunakan dalam penelitian ini antara lain erlenmeyer, cawan petri, autoklaf, laminar air flow cabinet, mikroskop majemuk, haematocytometer, gelas preparat, dan gelas penutup. Bahan-bahan yang diperlukan adalah isolat P. megakarya (isolat yang berasal dari Lampung Timur), kitosan (produksi Araminta Sidhakarya Tangerang Banten dalam pelarut asam asetat sehingga diperoleh $\mathrm{pH} 7,0$ ), alkohol $70 \%$, media V8, tembaga oksida $56 \%$, dan buah kakao hibrida lokal.

Jamur P. megakarya diisolasi dari buah kakao yang bergejala busuk buah. Bagian buah yang menunjukkan gejala busuk dipotong antara bagian sehat dan bagian yang sakit dengan ukuran 0,5 mm, kemudian direndam dengan $\mathrm{NaOCl}$ 0,5\% selama 15-30 detik, lalu dibilas dengan aquades steril dan ditiriskan. Potongan kakao diisolasi ke dalam media V8 dan diinkubasi selama 7 hari. Jamur P. megakarya yang tumbuh pada media V8 tersebut selanjutnya ditransfer pada media V8 agar mendapatkan kultur murni (dimodifikasi dari Adedeji et al., 2008). Jamur P. megakarya diisolasi dari buah kakao yang bergejala busuk buah. Bagian buah yang menunjukkan gejala busuk dipotong antara bagian sehat dan bagian yang sakit dengan ukuran $0,5 \mathrm{~mm}$, kemudian direndam dengan $\mathrm{NaOCl}$ 0,5\% selama 15-30 detik, lalu dibilas dengan aquades steril dan ditiriskan. Potongan kakao diisolasi ke dalam media V8 dan diinkubasi selama 7 hari. Jamur P. megakarya yang tumbuh pada media V8 tersebut selanjutnya ditransfer pada media V8 agar mendapatkan kultur murni (dimodifikasi dari Adedeji et al., 2008).

Pengamatan dilakukan dengan cara mengukur diameter koloni jamur bertujuan untuk mengetahui pertumbuhan jamur P. megakarya dan mengetahui kemampuan konsentrasi kitosan 
dalam menghambat pertumbuhan jamur P. megakarya secara in vitro, serta pengamatan kerapatan sporangium dihitung menggunakan metode hitungan mikroskopis langsung, yaitu sampel diletakkan pada haematocytometer. Perlakuan tersebut disusun dalam rancangan acak lengkap (RAL) terdiri dari (1) media V8 tanpa kitosan, (2) media V8 berkitosan 0,2\%, (3) media V8 berkitosan $0,4 \%$, (4) media V8 berkitosan $0,6 \%$, (5) media V8 berkitosan $0,8 \%$, dan (6) media V8 bertembaga oksida 56\%, masing-masing perlakuan diulang enam kali. Kemudian antar perlakuan diuji keragamannya dilanjutkan dengan uji jarak berganda Duncan pada taraf 5\%.

\section{HASIL DAN PEMBAHASAN}

Campuran kitosan pada media V8 menekan pertumbuhan koloni $P$. megakarya. Hal ini ditunjukkan pada pengamatan diameter koloni $P$. megakarya pada 2 sampai 7 hari inkubasi (Tabel 1). Pada pengamatan 6 hari inkubasi, pengaruh media V8 berkitosan terhadap diameter koloni $P$. megakarya berbeda nyata dibandingkan dengan pengaruh media V8 tanpa kitosan. Perlakuan media V8 berkitosan yang terbaik dalam menekan pertumbuhan $P$. megakarya adalah media V8 berkitosan $0,6 \%$, karena pengaruhnya terjadi sejak pengamatan 2 hari inkubasi. Kemampuan media V8 bertembaga oksida 56\% dalam menekan pertumbuhan koloni terjadi sejak 3 hari inkubasi.

Tabel 1. Diameter koloni P. megakarya $\left(\mathrm{cm} . \mathrm{cawan}^{-1}\right)$

\begin{tabular}{lcccccc}
\hline \multirow{2}{*}{ Perlakuan } & \multicolumn{6}{c}{ Diameter koloni P. megakarya $(\mathrm{cm})$ dalam masa inkubasi } \\
\cline { 2 - 7 } & 2 hari & 3 hari & 4 hari & 5 hari & 6 hari & 7 hari \\
\hline Media V8 tanpa kitosan & $0,55 \mathrm{a}$ & $0,63 \mathrm{a}$ & $0,72 \mathrm{a}$ & $0,79 \mathrm{a}$ & $0,83 \mathrm{a}$ & $0,97 \mathrm{a}$ \\
Media V8 kitosan 0,2\% & $0,58 \mathrm{a}$ & $0,62 \mathrm{a}$ & $0,64 \mathrm{a}$ & $0,75 \mathrm{a}$ & $0,75 \mathrm{~b}$ & $0,75 \mathrm{~b}$ \\
Media V8 kitosan 0,4\% & $0,53 \mathrm{a}$ & $0,59 \mathrm{a}$ & $0,60 \mathrm{a}$ & $0,61 \mathrm{a}$ & $0,61 \mathrm{~b}$ & $0,61 \mathrm{~b}$ \\
Media V8 kitosan 0,6\% & $0,32 \mathrm{~b}$ & $0,36 \mathrm{~b}$ & $0,41 \mathrm{~b}$ & $0,47 \mathrm{~b}$ & $0,47 \mathrm{~b}$ & $0,47 \mathrm{~b}$ \\
Media V8 kitosan 0,8\% & $0,43 \mathrm{a}$ & $0,45 \mathrm{~b}$ & $0,61 \mathrm{a}$ & $0,63 \mathrm{a}$ & $0,63 \mathrm{~b}$ & $0,63 \mathrm{~b}$ \\
Media bertembaga oksida 56\% & $0,54 \mathrm{a}$ & $0,54 \mathrm{~b}$ & $0,54 \mathrm{~b}$ & $0,55 \mathrm{~b}$ & $0,55 \mathrm{~b}$ & $0,55 \mathrm{~b}$ \\
\hline Nilai Duncan pada taraf 5\% & 0,10 & 0,09 & 0,07 & 0,06 & 0,02 & 0,02 \\
\hline
\end{tabular}

$\overline{\text { Keterangan: Angka yang diikuti oleh huruf yang sama pada kolom yang sama tidak berbeda nyata }}$ berdasarkan uji jarak berganda Duncan $(\alpha=0,05)$

Pemberian kitosan pada media V8 menurunkan kerapatan sporangium P. megakarya. Rerata kerapatan sporangium P. megakarya pada konsentrasi kitosan 0,6\% dan 0,8\% sama dengan 
kerapatan sporangium P. megakarya pada tembaga oksida 56\% (Tabel 2) dan disajikan pada Gambar 1.

Tabel 2. Rerata kerapatan sporangium P. megakarya pada pengamatan hari ke-6 setelah inkubasi

\begin{tabular}{lc}
\hline \multicolumn{1}{c}{ Perlakuan } & $\begin{array}{c}\text { Rerata kerapatan } \\
\left(\times 10^{6} \text { sporangium. } \mathrm{ml}^{-1}\right)\end{array}$ \\
\hline Media V8 tanpa kitosan & $1,40 \mathrm{a}$ \\
Media V8 kitosan 0,2\% & $1,03 \mathrm{a}$ \\
Media V8 kitosan 0,4\% & $0,94 \mathrm{a}$ \\
Media V8 kitosan 0,6\% & $0,45 \mathrm{~b}$ \\
Media V8 kitosan 0,8\% & $0,57 \mathrm{~b}$ \\
Media bertembaga oksida 56\% & $0,48 \mathrm{~b}$ \\
\hline
\end{tabular}

Nilai Duncan pada taraf 5\%: 0,37

Keterangan: Angka yang diikuti oleh huruf yang sama pada kolom yang sama tidak berbeda nyata berdasarkan uji jarak berganda Duncan $(\alpha=0,05)$

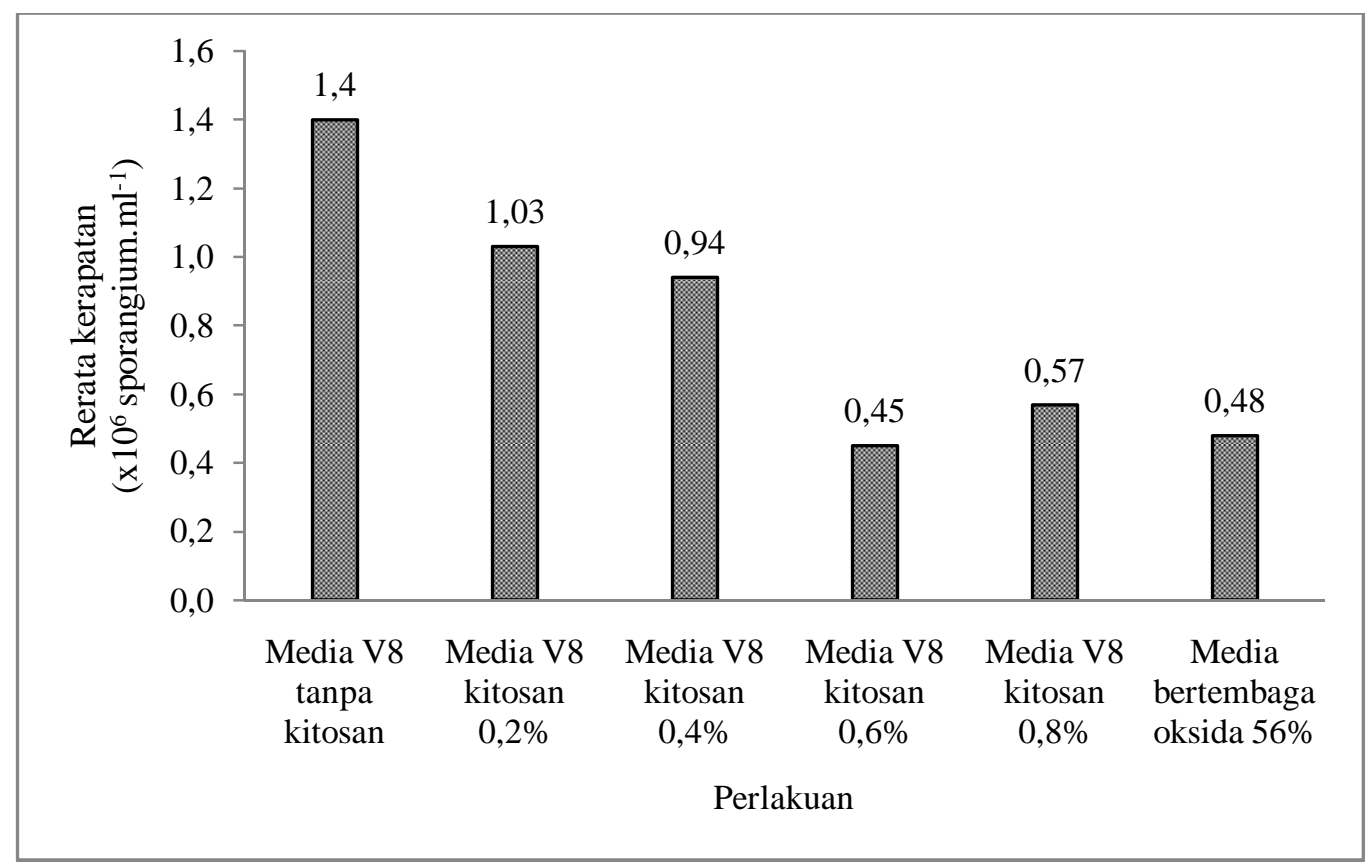

Gambar 1. Rerata kerapatan sporangium P. megakarya pada pengamatan hari ke-6 setelah inkubasi

Hasil penelitian secara in vitro menunjukkan kitosan dengan konsentrasi $0,6 \%$ dan $0,8 \%$ berpengaruh terhadap pertumbuhan koloni P. megakarya. Hal ini sesuai dengan penelitian Badawy 64

Jurnal AIP Volume 6 No. 2 | Oktober 2018: 61-66 
et al. (2011) yang menyatakan bahwa secara in vitro konsentrasi kitosan $0,5-6,0 \mathrm{mg} \cdot \mathrm{ml}^{-1}$ mampu menekan pertumbuhan koloni $F$. oxysporum, $R$. stolonifer, dan $P$. digitatum. Mekanisme pengaruh kitosan terhadap jamur yaitu kitosan mampu mengikat unsur nitrogen di dalam DNA jamur dan merusak dinding membran sel jamur, sehingga protein di dalam sel jamur menjadi tidak aktif (Simpson et al., 1997). Media V8 bertembaga oksida 56\% juga memiliki kemampuan yang sama dengan media V8 berkitosan. Mekanisme pengaruh tembaga oksida terhadap sporangium jamur $P$. megakarya, yaitu adanya akumulasi kompleks tembaga yang larut dalam air dengan asam amino atau hidroksi atau dikarboksi yang dikeluarkan oleh eksudat sporangium, selanjutnya logam-logam tembaga ini mendenaturasikan protein sehingga enzim dalam jamur yang merupakan protein menjadi tidak aktif (Nene, 1971).

\section{KESIMPULAN DAN SARAN}

\section{Kesimpulan}

Pertumbuhan koloni P. megakarya 6 hari setelah inkubasi pada media V8 yang berkitosan 0,4\%, 0,6\%, dan 0,8\% lebih tertekan dibandingkan pertumbuhan pada media V8 tanpa kitosan, demikian pula pertumbuhan koloni $P$. megakarya pada media V8 yang mengandung tembaga oksida $56 \%$.

\section{Saran}

Perlu frekuensi aplikasi kitosan yang lebih sering dan sinergisme antara aplikasi kitosan dan penggunaan agensia hayati terutama yang berupa jamur sebagai pengendali penyakit busuk buah kakao.

\section{UCAPAN TERIMA KASIH}

Terima kasih penulis ucapkan kepada Staf dan Operator di Laboratorium Hama dan Penyakit Tumbuhan Fakultas Pertanian serta kepada teman-teman yang tidak dapat saya sebutkan satu per satu yang telah banyak membantu proses penelitian ini.

\section{DAFTAR PUSTAKA}

Adedeji, A. R., Odebode, A. C., \& Agbeniyi, S. O. (2008). Bioassay of five trichoderma strains against Phytophthora megakarya (Cacao pod-rot) in Nigeria. Scientific Research and Essays, 3(9), 390-394.

Badawy, M. E., \& Rabea, E. I. (2011). A biopolymer chitosan and its derivatives as promising antimicrobial agents against plant pathogens and their applications in crop protection. International Journal of Carbohydrate Chemistry, 2011, 1-30. 
Duniway, J. M. (1983). Role of physical factors in the development of Phytophthora diseases. In D. C. Erwin, S. Bartnicki-Garcia, \& P. H. Tsao (Eds.), Phytophthora: Its Biology, Taxonomy, Ecology, and Pathology (pp. 175-187). Minnesota: The American Phytopathological Society.

Gotama, C. (2011). Kemampuan Kitosan Sebagai Pengendali Jamur Phytophthora palmivora L. Penyebab Penyakit Busuk Buah Kakao (Theobroma cacao L.) Secara In Vitro. Unpublished undergraduate thesis, Universitas Lampung, Bandar Lampung.

Lestari, P., \& Purnomo, P. (2018). Intensitas Serangan Hama Penggerek Batang Kakao di Perkebunan Rakyat Cipadang, Gedongtataan, Pesawaran. Jurnal Agro Industri Perkebunan, 6(1), 1-8.

Nene, Y. L. (1971). Fungicide in Plant Disease Control. New Delhi: Oxford \& IBH Publishing Co.

Prameswita, W., Ismono, R. H., \& Viantimala, B. (2014). Faktor-Faktor yang Mempengaruhi Volume Ekspor Kakao Provinsi Lampung. Jurnal Ilmu-Ilmu Agribisnis, 2(1), 1-7.

Prasetyaningrum, A., Rokhati, N., \& Purwintasari, S. (2007). Optimasi derajat deasetilasi pada proses pembuatan chitosan dan pengaruhnya sebagai pengawet pangan. Jurnal Riset dan Iptek, 1, 39-46.

Ramlan. (2010). Pengelolaan penyakit busuk buah kakao. In: Prosiding Seminar Ilmiah dan Pertemuan Tahunan PEI dan PFI XX Komisariat Daerah Sulawesi Selatan. pp. 380-387.

Semangun, H. (1996). Penyakit-Penyakit Tanaman Perkebunan di Indonesia. Yogyakarta: Gadjah Mada University Press.

Simpson, B. K., Gagne, N., Ashie, I. N. A., \& Noroozi, E. (1997). Utilization of chitosan for preservation of raw shrimp (Pandalus borealis). Food Biotechnology, 11(1), 25-44. 